\title{
Preparation of Rat Gingival Mitochondria with an Improved Isolation Method
}

\author{
Noriaki Kaneko, ${ }^{1}$ Tetsuya Rikimaru, ${ }^{1}$ Tetsuyuki Fujimura, ${ }^{2}$ Shigeyasu Mori, ${ }^{3}$ \\ Saburo Hidaka, ${ }^{1}$ and Hidehiro Kaya ${ }^{1}$ \\ ${ }^{1}$ Department of Dental Hygiene, Fukuoka College of Health Sciences, 2-15-1 Tamura, Sawara-Ku, Fukuoka 814-0193, Japan \\ ${ }^{2}$ Fujimura Clinic, Fukuoka, Japan \\ ${ }^{3}$ Hamadayama Smile Dental Clinic, Tokyo, Japan
}

Correspondence should be addressed to Noriaki Kaneko, nokaneko@kyushu-ns.ac.jp

Received 26 July 2010; Revised 29 September 2010; Accepted 7 October 2010

Academic Editor: Michael E. Razzoog

Copyright ( 92010 Noriaki Kaneko et al. This is an open access article distributed under the Creative Commons Attribution License, which permits unrestricted use, distribution, and reproduction in any medium, provided the original work is properly cited.

In order to establish a method of obtaining rat gingival mitochondria (Mt), Mt fractions were prepared in various combinations of homogenizing time with collagenase concentration. Rat gingival tissues were excised, minced, treated with collagenase, homogenized, and subjected to differential centrifugation rates. Both the respiratory control ratio (RCR) and adenosine diphosphate/oxygen $(\mathrm{ADP} / \mathrm{O})$ ratio of the Mt fraction prepared in a combination of 40, 50, or 60 sec homogenization with collagenase in a concentration range of $0.115 \%-0.130 \%(\mathrm{w} / \mathrm{v})$ were measured. The values for the RCR and ADP/O ratio of the Mt fraction obtained in an optimal condition was $1.80 \pm 0.05$ and $1.65 \pm 0.03$, respectively. These results suggest that Mt of fairly high quality can be obtained through this refined combination of the homogenizing time and collagenase concentration.

\section{Introduction}

Mitochondria play a central role in the energy metabolism of brain, heart, and muscle by controlling the production of adenosine triphosphate (ATP), and mitochondrial preparations are commonly used to evaluate the metabolic activities of these tissues in both the normal and diseased states [1]. However, oxidative phosphorylation (ATP synthesis) and electron transport in oral tissues, for example, the oral mucosa and gingival tissue, were extensively studied in a period of the late 1970s to early 1980s by several investigators [2-8]. Mitochondria in the oral tissues of animals and humans have been isolated by differential centrifugation of tissue homogenates with or without collagenase treatment [2-5]. Moreover, to avoid the destruction of mitochondria or the loss of respiratory activity, chilled buffer solutions of an isotonic tension have generally been adopted. However, those studies have yielded variable and generally low levels of respiration both in the presence and absence of substrate, and the quantitative assessment of mitochondrial ATP synthesis in oral tissues has been hindered by the extreme difficulty of homogenizing these tissues without damaging mitochondrial integrity and uncoupling oxidative phosphorylation [4]. Therefore, further refinements for the isolation method are still required to obtain mitochondria with high quality.

Clarification of the role played by oxidative phosphorylation in gingival tissue metabolism would aid in the understanding of responses to local injury and periodontal disease. For example, collagen is a primary constituent of gingival tissue, and its synthesis and remodeling during periodontal tissue repair have been reported to be affected by diabetes [9], scurvy [10], and growth factors [11]. The events which affect these repair activities may also reflect changes at the oxidative phosphorylation level, since ATP is required for many synthetic processes associated with collagen synthesis.

We report here a procedure for the isolation of mitochondria from rat gingival tissues by an optimized combination between homogenizing time and collagenase concentration, which displayed a good respiratory control ratio (RCR) and adenosine diphosphate/oxygen $(\mathrm{ADP} / \mathrm{O})$ ratio using succinic acid as the substrate. Furthermore, the effect on respiratory 
activity of the leukotoxin (Lx) and lipopolysaccharide (LPS) involved in the inflamed state was examined.

\section{Materials and Methods}

2.1. Chemicals. Chemicals used where mannitol, sucrose, potassium chloride $(\mathrm{KCl})$, potassium dihydrogen phosphate $\left(\mathrm{KH}_{2} \mathrm{PO}_{4}\right)$, succinic acid, rotenone, and adenosine $5^{\prime}$ diphosphate sodium salt (ADP) and bovine serum albumin (BSA) were purchased from Sigma-Aldrich Japan Co. (Tokyo, Japan). Collagenase from Clostridium histolyticum (Type I), 3-N-morpholinopropanesulfonic acid (MOPS), 4Na-ethylenediaminetetraacetic acid (EDTA), and N-2hydroxyethylpiperazine- $\mathrm{N}^{\prime}$-2-ethansulfonic acid (HEPES) were purchased from Sigma-Aldrich Co. (St Louis, MO, USA). Leukotoxin ( $\mathrm{Lx})$ is a product of Cayman Chemicals Co., USA and lipopolysaccaride (LPS) from Escherichia coli is a product of Difco Laboratories, Mich, USA. Other reagents were purchased from ABIOZ Co. Ltd (Osaka, Japan).

2.2. Animals. Seven-to-nine week-old male Wistar rats, weighing 250-300 g were purchased from Seac Yoshitomi Ltd (Fukuoka Prefecture).

2.3. Preparation of Gingival Mitochondria. After sacrificing the rats by cervical dislocation under chloroform anesthesia, the gingival tissue specimen (approximately $1.0 \mathrm{~g}$ wet weight) was excised from the mandible and maxilla. As shown in Figure 1, tissue specimens were washed and minced with $5.0 \mathrm{mM}$ MOPS buffer (pH 7.4) containing $200 \mathrm{mM}$ mannitol, $70 \mathrm{mM}$ sucrose and $0.05 \mathrm{mM}$ EDTA at $4^{\circ} \mathrm{C}$. Minced gingival specimens were diluted 10 fold with $1.2 \mathrm{mM}$ MOPS buffer ( $\mathrm{pH} 7.4$ ) containing $53.9 \mathrm{mM}$ mannitol, $17.2 \mathrm{mM}$ sucrose, $0.05 \mathrm{mM}$ EDTA and $0.1 \%(\mathrm{w} / \mathrm{v}) \mathrm{BSA}$, and then intermittently homogenized at $4^{\circ} \mathrm{C}$ using a polytron homogenizer (RT 10-35, Kinematic AG, Lucerne, Switzerland) for 40, 50, and $60 \mathrm{sec}$. The homogenized gingival sample was then centrifuged at 4,500 g for $10 \mathrm{~min}$, the supernatant was labeled as $\mathrm{S} 1$ and the sediment was incubated in a Hanks solution ( $\mathrm{pH} 7.4)$ containing $0.115 \%-0.130 \%(\mathrm{w} / \mathrm{v})$ collagenase at $20^{\circ} \mathrm{C}$ for $20 \mathrm{~min}$. Following the enzymatic treatment, the homogenized gingival sample was centrifuged at $4,500 \mathrm{~g}$ for $10 \mathrm{~min}$. While the supernatant was labeled as S2, the sediment was diluted with $50 \mathrm{mM}$ MOPS buffer containing $100 \mathrm{mM} \mathrm{KCl}, 0.2 \mathrm{mM}$ EDTA, and $0.2 \%(\mathrm{w} / \mathrm{v}) \mathrm{BSA}$ and homogenized using a teflon homogenizer for one min. The homogenate was centrifuged at $600 \mathrm{~g}$ for $10 \mathrm{~min}$ and the sediment was collected as the nuclear $(\mathrm{N})$ fraction. The supernatant was then centrifuged at $4,500 \mathrm{~g}$ for $10 \mathrm{~min}$, the supernatant was labeled as $\mathrm{S} 3$ and the sediment was finally collected as the mitochondrial (Mt) fraction.

2.4. Specific Activity of Succinate Dehydrogenase (SDH). The specific activity of succinate dehydrogenase (SDH) was measured by a modified Slater method [12]. The ability of both the supernatant fractions S1, S2, and S3 and the sediment fractions $\mathrm{N}$ and $\mathrm{Mt}$ to reduce potassium ferricyanide was measured. Protein was determined by the
Lowry Folin phenol reagent method [13] using BSA as a standard.

2.5. Measurement of the Oxidative Phosphorylation. The oxidative phosphorylation of gingival mitochondria was measured using a Biological Oxygen Monitor System (Model 5300: YSI Inc., Ohio, USA). Based on the oxygen consumption of the mitochondrial factions at $25^{\circ} \mathrm{C}$, states 1 , 3 , and 4 , that were established by Chance et al. [14], were calculated. Namely, a final concentration of $0.5 \mathrm{mg}$ protein $/ 600 \mu \mathrm{L}$ buffer of gingival mitochondria was suspended in $600 \mu \mathrm{L}$ of $10 \mathrm{mM}$ HEPES buffer ( $\mathrm{pH}$ 7.4) containing $0.25 \mathrm{M}$ sucrose and $10 \mathrm{mM} \mathrm{KH}_{2} \mathrm{PO}_{4}$ in the reaction container of an oxygen electrode apparatus, followed by the addition of $100 \mu \mathrm{g} / \mathrm{mL}$ rotenone and $0.6 \mathrm{mM}$ succinic acid (See Figure 2). After measuring states 1,3 , and 4 , the respiration activity of gingival mitochondria was assessed by measuring (1) respiratory control ratio (RCR): the respiratory rate (State 3 ) in the presence of ADP compared to the rate (State 4) following the expenditure of ADP and (2) the adenosine diphosphate/oxygen $(\mathrm{ADP} / \mathrm{O})$ ratio: the ratio of ADP removed from the media to the amount of oxygen consumed, according to the Estabrook method [15].

2.6. Effects of Leukotoxin and Lipopolysaccharide on Respiratory Control Ratio (RCR) of Mitochondria. At a concentration range of $0.5-2.0 \mu \mathrm{g} / \mathrm{mg}$ mitochondrial $(\mathrm{Mt})$ protein, leukotoxins (Lxs) were added to a $600 \mu \mathrm{L}$ of $10 \mathrm{mM}$ HEPES buffer ( $\mathrm{pH}$ 7.4) containing $0.25 \mathrm{M}$ sucrose and $10 \mathrm{mM}$ $\mathrm{KH}_{2} \mathrm{PO}_{4}$ in the reaction container of an oxygen electrode apparatus, followed by the addition of $100 \mu \mathrm{g} / \mathrm{mL}$ rotenone and $0.6 \mathrm{mM}$ succinic acid. At a concentration range of 5.0$25.0 \mu \mathrm{g} / \mathrm{mg}$ Mt protein, lipopolysaccharide (LPS) was added in the same manner. After measuring states 1, 3, and 4, the respiration activity of gingival mitochondria was assessed by measuring RCR in the same manner as described above.

2.7. Ethics. The mitochondrial preparations from rats were carried out at the Fukuoka Dental College, and the study was approved by the Institutional Use and Care of Animal Committee. All procedures were in accordance with the Guidelines on Animal Experiments in Fukuoka Dental College and performed following the Government Law Concerning the Protection and Control of Animals (no. 221) and Japanese Government Notification on Feeding and Safekeeping of Animals (no. 6).

2.8. Statistical Analysis. The data were obtained from 5 times measurements and were expressed as the mean \pm standard deviations. Statistical comparisons were made by ANOVA and Scheffe's test using a statistical software program. $P<.05$ was considered significant.

\section{Results}

3.1. Succinate Dehydrogense (SDH) Activity in the Different Fractions in the Process of Mitochondrial Isolation. Rat 


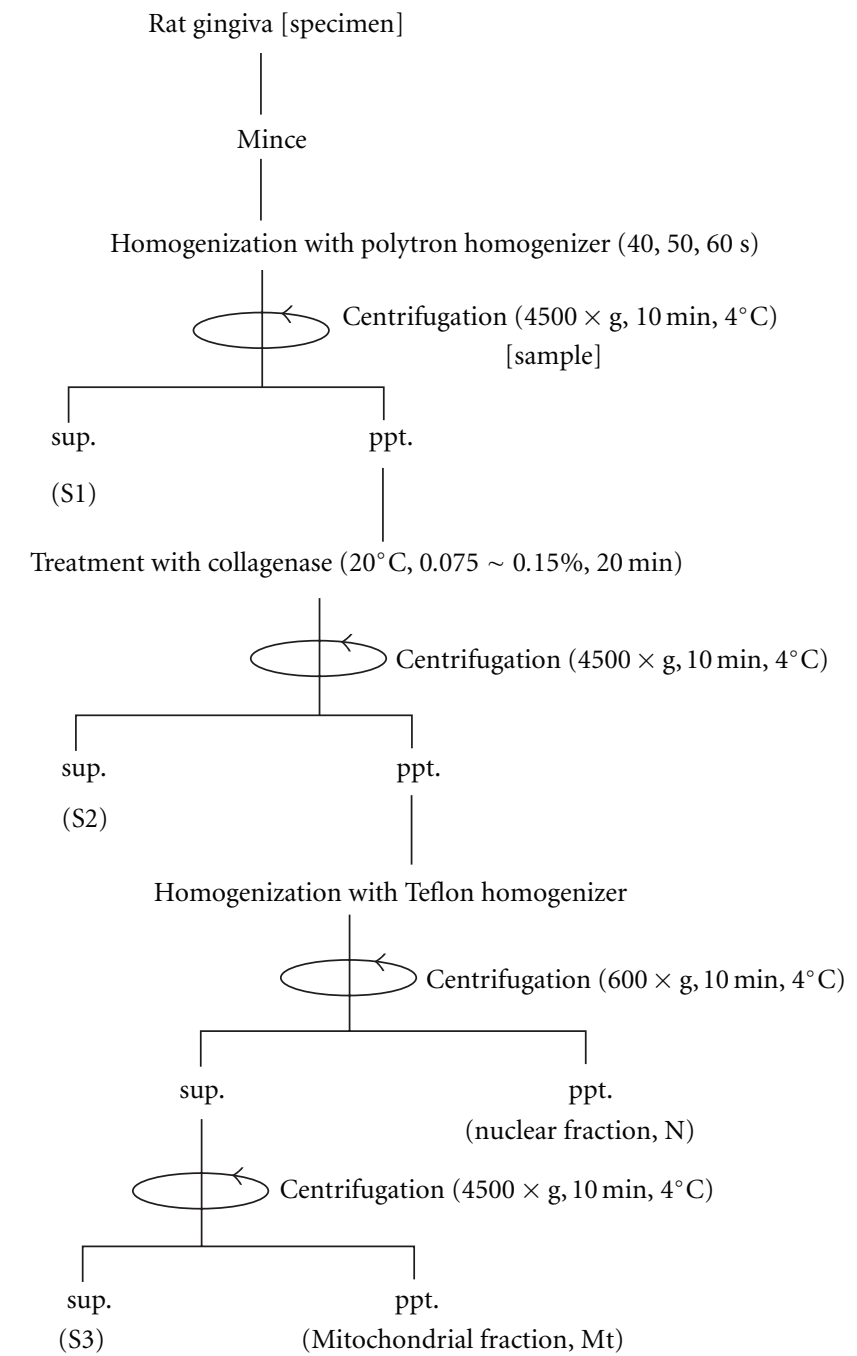

Figure 1: Diagrammatic representation of the mitochondrial $(\mathrm{Mt})$ preparation procedure from gingival tissue in rats. Tissue specimens were washed and minced with $5.0 \mathrm{mM}$ MOPS buffer $\left(\mathrm{pH}\right.$ 7.4) and then intermittently homogenized at $4^{\circ} \mathrm{C}$ using a polytron homogenizer for 40, 50, and $60 \mathrm{sec}$. The homogenized gingival sample was centrifuged at 4,500 g for $10 \mathrm{~min}$, the supernatant was labeled as S1, and the sediment was incubated in a Hanks solution ( $\mathrm{pH} 7.4$ ) containing $0.115 \%-0.130 \%\left(\mathrm{w} / \mathrm{v}\right.$ ) collagenase at $20^{\circ} \mathrm{C}$ for $20 \mathrm{~min}$. Following the enzymatic treatment, the homogenized gingival sample was centrifuged at 4,500 g for $10 \mathrm{~min}$. When the supernatant is labeled S2, the sediment was diluted with $50 \mathrm{mM}$ MOPS buffer containing $100 \mathrm{mM} \mathrm{KCl,} 0.2 \mathrm{mM}$ EDTA, and $0.2 \%$ (w/v) BSA and homogenized using a Teflon homogenizer for one min. The homogenate was centrifuged at $600 \mathrm{~g}$ for $10 \mathrm{~min}$ and the sediment was collected as the nuclear (N) fraction. The supernatant was then centrifuged at 4,500 g for $10 \mathrm{~min}$, the supernatant was labeled as S3, and the sediment was finally collected as the mitochondrial $(\mathrm{Mt})$ fraction.

gingival tissues were processed in the course of mitochondrial isolation (Figure 1). The first, second, and third supernatant fractions were designated as S1, S2, and S3, respectively, while the two precipitates were designated as the nuclear $(\mathrm{N})$ and mitochondrial $(\mathrm{Mt})$ fractions. As shown in Table 1, when the three supernatant and two precipitated fractions were obtained in the combination of $50 \mathrm{sec}$ homogenization with $0.120 \%(\mathrm{w} / \mathrm{v})$ collagenase treatment, the specific activities of succinate dehydrogense $(\mathrm{SDH})$ in the S1, S2, and S3 fractions were $0.51 \pm 0.05$, $0.72 \pm 0.05$, and $0.22 \pm 0.02$, respectively, whereas those of $\mathrm{N}$ and Mt precipitated fractions were $0.25 \pm 0.02$ and $5.67 \pm 0.32$, respectively.
3.2. The Respiratory Control Ratio (RCR) and Adenosine Diphosphate/Oxygen (ADP/O ) Ratio in Mitochondrial Fractions. As shown in Table 2, after $40 \mathrm{sec}$ homogenization with $0.125 \%(\mathrm{w} / \mathrm{v})$ collagenase treatment of the Mt fraction, the values of the respiratory control ratio (RCR), and adenosine diphosphate/oxygen $(\mathrm{ADP} / \mathrm{O})$ ratio were $1.54 \pm 0.02$ and $1.39 \pm 0.05$, respectively. After $50 \mathrm{sec}$ homogenization with $0.120 \%(\mathrm{w} / \mathrm{v})$ collagenase treatment of the Mt fraction, the $\mathrm{RCR}$ and $\mathrm{ADP} / \mathrm{O}$ values were $1.80 \pm 0.05$ and $1.65 \pm 0.03$, respectively. Further, after homogenization for $60 \mathrm{sec}$ with $0.120 \%(\mathrm{w} / \mathrm{v})$ collagenase treatment of Mt fraction, the Mt fraction RCR and ADP/O values were $1.57 \pm 0.03$ and $1.49 \pm 0.01$, respectively. The values of the Mt fraction in 


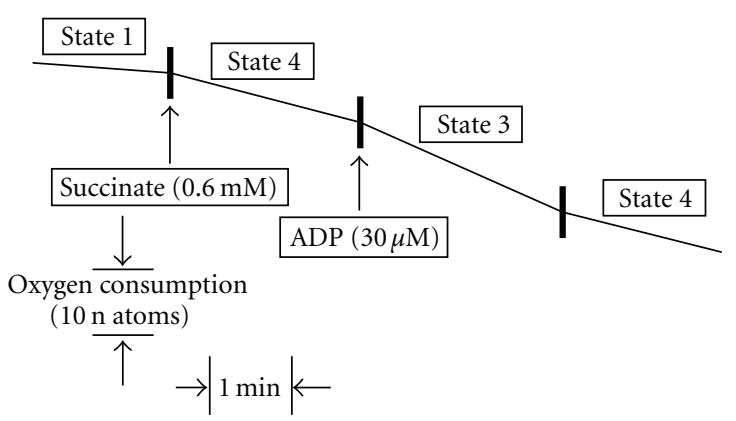

Figure 2: A polarographic trace of gingival mitochondria (Mt). Mt were prepared from approximately $1.0 \mathrm{~g}$ rat gingival tissue using an optimized preparative procedure displaying apparent respiratory activity. The preparation conditions are $50 \mathrm{sec}$ of polytron homogenizer treatment and $0.120 \%(\mathrm{w} / \mathrm{v})$ collagenase. Oxygen consumption by the gingival Mt $(0.5 \mathrm{mg}$ protein/ $600 \mu \mathrm{L}$ buffer $)$ was measured with the addition of substrate $(0.6 \mathrm{mM}$ succinate) followed by $30 \mu \mathrm{M}$ adenosine diphosphate (ADP) at $25^{\circ} \mathrm{C}$.

TABLE 1: Specific activity of succinate dehydrogenase (SDH) in the various fractions in the process of mitochondrial isolation.

\begin{tabular}{ll}
\hline Fractions & $\begin{array}{l}\text { Specific activity } \\
\text { (U/mg protein) }\end{array}$ \\
\hline S1 & $0.51 \pm 0.05^{*}$ \\
S2 & $0.72 \pm 0.05^{*}$ \\
S3 & $0.22 \pm 0.02^{*}$ \\
N & $0.25 \pm 0.02^{*}$ \\
Mt & $5.67 \pm 0.32$ \\
\hline
\end{tabular}

S1, S2, and S3 designate the first, second, and third supernatant fractions in the process of mitochondrial isolation, respectively, while $\mathrm{N}$ and $\mathrm{Mt}$ designate the precipitated fractions of the nuclei and mitochondria, respectively, (see Figure 1). Enzymatic digestion was carried out under the conditions of $0.120 \%(\mathrm{w} / \mathrm{v})$ collagenase for $20 \mathrm{~min}$ with $50 \mathrm{sec}$ homogenization. Specific activity of succinate dehydrogenase was measured by the modified Slater method [12].

* Significantly different compared with the mitochondrial (Mt) fraction, $P<.05$.

the $50 \mathrm{sec}$ homogenization with $0.120 \%$ (w/w) collagenase treatment were significantly the highest.

3.3. Effects of Leukotoxin and Lipopolysaccharide on Respiratory Control Ratio (RCR) of Mitochondrial Fractions. As shown in Table 3, at a concentration range of $0.5-2.0 \mu \mathrm{g} / \mathrm{mg}$ Mt protein, leukotoxin (Lx) decreased the RCR of the Mt fractions by $29 \%, 37 \%$, and $42 \%$ respectively, compared to the control (None). Furthermore, at a concentration range of $5.0-25.0 \mu \mathrm{g} / \mathrm{mg} \mathrm{Mt}$ protein, lipopolysaccharide (LPS) decreased the RCR of the Mt fractions by $31 \%$, 38\%, and $40 \%$ respectively, compared to the control (none).

\section{Discussion}

There are a few reports in the literature on the preparation of mitochondria (Mt) from epithelial tissue for the purpose of the direct measurement of respiratory activity $[2-7,16$, 17]. However, neither the damage to fibroblasts in $\mathrm{Mt}$
TABLE 2: Respiratory control ratio (RCR) and adenosine diphosphate/oxygen (ADP/O) ratio in mitochondrial fractions from rat gingival tissues.

\begin{tabular}{lll}
\hline $\begin{array}{l}\text { Concentration of } \\
\text { collagenase }[\%(w / v)]\end{array}$ & $\begin{array}{l}\text { Respiratory } \\
\text { control ratio }\end{array}$ & ADP/O ratio \\
\hline Homogenized for $40 \mathrm{sec}$ & $1.27 \pm 0.04$ & $1.20 \pm 0.06$ \\
0.120 & $1.54 \pm 0.02$ & $1.39 \pm 0.05$ \\
0.125 & $1.43 \pm 0.04$ & $1.25 \pm 0.02$ \\
0.130 & & \\
Homogenized for $50 \mathrm{sec}$ & $1.45 \pm 0.03$ & $1.36 \pm 0.03$ \\
0.115 & $1.80 \pm 0.05^{* * * *}$ & $1.65 \pm 0.03^{* * * *}$ \\
0.120 & $1.39 \pm 0.04$ & $1.28 \pm 0.03$ \\
0.125 & & \\
Homogenized for $60 \mathrm{sec}$ & $1.50 \pm 0.03$ & $1.42 \pm 0.02$ \\
0.115 & $1.57 \pm 0.03$ & $1.49 \pm 0.01$ \\
0.120 & $1.33 \pm 0.05$ & $1.23 \pm 0.03$ \\
0.125 &
\end{tabular}

The respiratory control ratio (RCR) and adenosine diphosphate/oxygen $(\mathrm{ADP} / \mathrm{O})$ ratio of the mitochondrial $(\mathrm{Mt})$ fractions which were obtained by varying the concentration of collagenase and the time of homogenization were measured. After measuring states 1, 3, and 4, the respiratory activity of gingival Mt was assessed by measuring (1) the respiratory control ratio (RCR): the ratio of the respiratory rate (State 3 ) in the presence of ADP to the rate (State 4) following the expenditure of ADP and (2) adenosine diphosphate/oxygen $(\mathrm{ADP} / \mathrm{O})$ ratio: the ratio of $\mathrm{ADP}$ removed from the media to the amount of oxygen consumed, according to the Estabrook method [15].

* Significantly different in terms of the highest values between $40 \mathrm{sec}$ and 50 sec homogenizing at $P<.05$.

** Significantly different in terms of the highest values between $50 \mathrm{sec}$ and 60 sec homogenizing at $P<.05$.

TABLE 3: Effects of leukotoxin and lipopolysaccharide on the respiratory control ratio (RCR) in mitochondrial fractions from rat gingival tissues.

\begin{tabular}{|c|c|c|}
\hline & $\begin{array}{l}\text { Concentration used } \\
\left(\mu \mathrm{g} / \mathrm{mg} \mathrm{Mt} \mathrm{protein}^{\mathrm{a}}\right)\end{array}$ & $\begin{array}{c}\text { Respiratory control } \\
\text { ratio }\end{array}$ \\
\hline Control (none) & 0.0 & $1.82 \pm 0.05$ \\
\hline \multirow[t]{3}{*}{ Leukotoxin } & 0.5 & $1.29 \pm 0.05^{*}$ \\
\hline & 1.0 & $1.15 \pm 0.03^{*}$ \\
\hline & 2.0 & $1.05 \pm 0.03^{*}$ \\
\hline \multicolumn{3}{|c|}{ Lipopolysaccharide } \\
\hline & 5.0 & $1.26 \pm 0.03^{*}$ \\
\hline & 10.0 & $1.13 \pm 0.03^{*}$ \\
\hline & 25.0 & $1.10 \pm 0.03^{*}$ \\
\hline
\end{tabular}

The respiratory control ratio (RCR) of the mitochondrial (Mt) fractions which was obtained from the conditions of $0.120 \%(\mathrm{w} / \mathrm{v})$ collagenase treatment and $50 \mathrm{sec}$ homogenization. At a concentration range of $0.5-$ $2.0 \mu \mathrm{g} / \mathrm{mg}$ Mt protein, leukotoxin was added to a $600 \mu \mathrm{L}$ of $10 \mathrm{mM}$ HEPES buffer ( $\mathrm{pH} 7.4$ ) containing $0.25 \mathrm{M}$ sucrose and $10 \mathrm{mM} \mathrm{KH}_{2} \mathrm{PO}_{4}$ in the reaction container of an oxygen electrode apparatus, followed by the addition of $100 \mu \mathrm{g} / \mathrm{mL}$ rotenone and $0.6 \mathrm{mM}$ succinic acid. Also, at a concentration range of 5.0-25.0 $\mu \mathrm{g} / \mathrm{mg}$ Mt protein, lipopolysaccharide was added in the same manner. RCR was determined polarographically, as shown in Table 2.

${ }^{\mathrm{a}} \mathrm{Mt}$ protein; mitochondrial protein.

* Significantly different when compared with the control (none) at $P<.05$. 
disease [16] nor the effect of nicotine on $\mathrm{Mt}$ in periodontal tissues [17] has ever been reportedly investigated by the measurement of respiratory activity. Moreover, Rosett et al. [2] have suggested that it is impossible to prepare Mt from attached gingival tissue, because of the presence of collagen, which disturbs the isolation of Mt. In the present study of gingival Mt preparation, the changes of the duration of the homogenization time and the concentration of collagenase were investigated. Succinic acid dehydrogenase (SDH) is an enzyme localized within cells in the Mt matrix and an important step in the Krebs cycle $[13,17]$. The specific activity of SDH from the Mt fraction was higher by 7.825.8 times in the three supernatants, S1, S2, and S3, and compared with the one precipitated in the $\mathrm{N}$ fractions (Table 1). This indicates that Mt were obtained through this isolation method that is a combination of a certain specific homogenization time and collagenase concentration. The combined conditions of $50 \mathrm{sec}$ homogenization with $0.120 \%(\mathrm{w} / \mathrm{v})$ collagenase concentration yielded $1.80 \pm 0.05$ as the respiratory control ratio (RCR) and $1.65 \pm 0.03$ as the adenosine diphosphate/oxygen ratio (ADP/O). Fine et al. [4] reported that the $\mathrm{RCR}$ and $\mathrm{ADP} / \mathrm{O}$ ratio from a crude Mt preparation of weanling rat attached gingiva for succinate were $4.0 \pm 0.2$ and $1.6 \pm 0.1$, respectively. McCoy [3] also reported the RCR value in epithelial Mt after collagenase dissociation of hamster cheek pouch oral mucosa for succinate to be 2.45 , without any reported value for the $\mathrm{ADP} / \mathrm{O}$ ratio. Our value of $1.65 \pm 0.03$ for $\mathrm{RCR}$ is $73 \%$ of that reported by McCoy [3].

In terms of the relationship between metabolism and the function of polymorphonuclear cells (PMNs), it has been established that the chemotactic, phagocytic, and microbicidal activities of these cells are strongly dependent upon their oxidative metabolic process which is driven by Mt [8]. Leukotoxins (Lxs) are a group of exotoxins that produce their primary toxic effects against leukocytes, especially PMNs [18]. Suliman et al. [19] reported that lipopolysaccharide (LPS) exhibited an endotoxic damage on the respiratory function of rat heart Mt. Both commercial Lx and LPS in this study effectively inhibited the respiratory activity of rat gingival Mt (Table 3). This fact suggests that both Lx and LPS may be involved in the attenuated Mt function of inflamed gingival tissues.

In conclusion, rat gingival tissue $\mathrm{Mt}$ were isolated using the conditions of $50 \mathrm{sec}$ polytron homogenization and $0.120 \%(\mathrm{w} / \mathrm{v})$ collagenase concentration. The quality of this Mt preparation was confirmed by the demonstrated higher activity of SDH. Furthermore, the quality the Mt preparation was certified by both respiratory parameters such as RCR and ADP/O ratio. Finally, it was found that the RCR of Mt was decreased by both an exotoxin, Lx, and an endotoxin, LPS.

\section{Acknowledgment}

Present address of Noriaki Kaneko; Department of Oral Health Sciences, Kyushu University of Nursing and Social Welfare, 888 Tomio, Tamana City, Kumamoto 865-0062, Japan.

\section{References}

[1] D. L. Johannsen and E. Ravussin, "The role of mitochondria in health and disease," Current Opinion in Pharmacology, vol. 9, no. 6, pp. 780-786, 2009.

[2] T. Rosett, L. P. Gangarosa Sr., E. L. Ashbridge et al., "Respiration of homogenates and crude mitochondrial fractions of bovine attached gingiva," Archives of Oral Biology, vol. 17, no. 11, pp. 1543-1550, 1972.

[3] G. D. McCoy, "Respiratory characteristics of mitochondria isolated from squamous epithelium of the hamster cheek pouch," Proceedings of the Society for Experimental Biology and Medicine, vol. 156, no. 1, pp. 118-122, 1977.

[4] A. S. Fine, R. W. Egnor, E. Forrester, I. W. Scopp, and S. S. Stahl, "Oxidative phosphrylation in rat oral mucosal mitochondria," Journal of Investigative Dermatology, vol. 70, pp. 16-20, 1978.

[5] A. S. Fine, R. W. Egnor, I. W. Scopp, and S. S. Stahl, "Subcellular distribution and partial characterization of gingival mitochondrial and soluble malate dehydrogenases," Journal of Periodontal Research, vol. 13, no. 3, pp. 215-223, 1978.

[6] A. S. Fine, R. W. Egnor, E. Forrester, and S. S. Stahl, "Elastase \pm soybean trypsin inhibitor dissociation of rat oral mucosa: ultrastructural and oxidative metabolic destructive changes in isolated, epithelial and dermal mitochondria after dissociation," Journal of Investigative Dermatology, vol. 76, no. 4, pp. 239-245, 1981.

[7] A. S. Fine, R. W. Egnor, E. Forrester, and S. S. Stahl, "Adenylate cyclase localization in unfixed specimens of rat oral mucosa and isolated mitochondria," Journal of Histochemistry and Cytochemistry, vol. 30, no. 11, pp. 1171-1178, 1982.

[8] A. S. Fine and P. Person, "Biochemistry of gingival oxidative metabolism: a review," Journal of Oral Pathology, vol. 13, no. 3 , pp. 191-212, 1984.

[9] Z. Yu, N. S. Ramamurthy, M. Leung, K. M. Chang, T. F. McNamara, and L. M. Golub, "Chemically-modified tetracycline normalizes collagen metabolism in diabetic rats: a doseresponse study," Journal of Periodontal Research, vol. 28, no. 6 I, pp. 420-428, 1993.

[10] D. E. Kipp, M. McElvain, D. B. Kimmel, M. P. Akhter, R. G. Robinson, and B. P. Lukert, "Scurvy results in decreased collagen synthesis and bone density in the guinea pig animal model," Bone, vol. 18, no. 3, pp. 281-288, 1996.

[11] X. E. Dereka, C. E. Markopoulou, and I. A. Vrotsos, "Role of growth factors on periodontal repair," Growth Factors, vol. 24, no. 4, pp. 260-267, 2006.

[12] C. D. Veeger, D. V. Vartanian, and W. P. Zeylemaker, "Spectrophotometric method with $\mathrm{KM}_{3} \mathrm{Fe}(\mathrm{CN})_{6}$," in Citric Acid Cycle, J. M. Lowenstein, Ed., pp. 81-84, Academic Press, New York, NY, USA, 1969.

[13] O. H. Lowry, N. J. Rosebrough, A. L. Farr, and R. J. Randall, "Protein measurement with the Folin phenol reagent," The Journal of Biological Chemistry, vol. 193, no. 1, pp. 265-275, 1951.

[14] B. Chance, A. Azzi, I. Y. Lee, C. P. Lee, and L. Mela, "Structure and function," in Mitochondria, L. Ernster and Z. Drahota, Eds., pp. 233-273, Academic Press, New York, NY, USA, 1969.

[15] R. W. Estabrook, "Mitochondrial respiratory control and the polarographic measurement of ADP:O ratios," in Methods in Enzymology, R. W. Estabrook and M. E. Pullman, Eds., vol. 10, pp. 41-47, Academic Press, New York, NY, USA, 1967.

[16] P. Briones, M. A. Vilaseca, A. Ribes et al., "A new case of multiple mitochondrial enzyme deficiencies with decreased 
amount of heat shock protein 60," Journal of Inherited Metabolic Disease, vol. 20, no. 4, pp. 569-577, 1997.

[17] J. Lahmouzi, F. Simain-Sato, M. P. Defresne et al., "Effect of nicotine on rat gingival fibroblasts in vitro," Connective Tissue Research, vol. 41, no. 1, pp. 69-80, 2000.

[18] S. K. Narayanan, T. G. Nagaraja, M. M. Chengappa, and G. C. Stewart, "Leukotoxins of gram-negative bacteria," Veterinary Microbiology, vol. 84, no. 4, pp. 337-356, 2002.

[19] H. B. Suliman, K. E. Welty-Wolf, M. Carraway, L. Tatro, and C. A. Piantadosi, "Lipopolysaccharide induces oxidative cardiac mitochondrial damage and biogenesis," Cardiovascular Research, vol. 64, no. 2, pp. 279-288, 2004. 


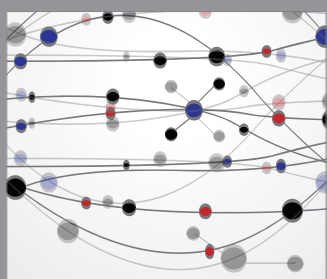

The Scientific World Journal
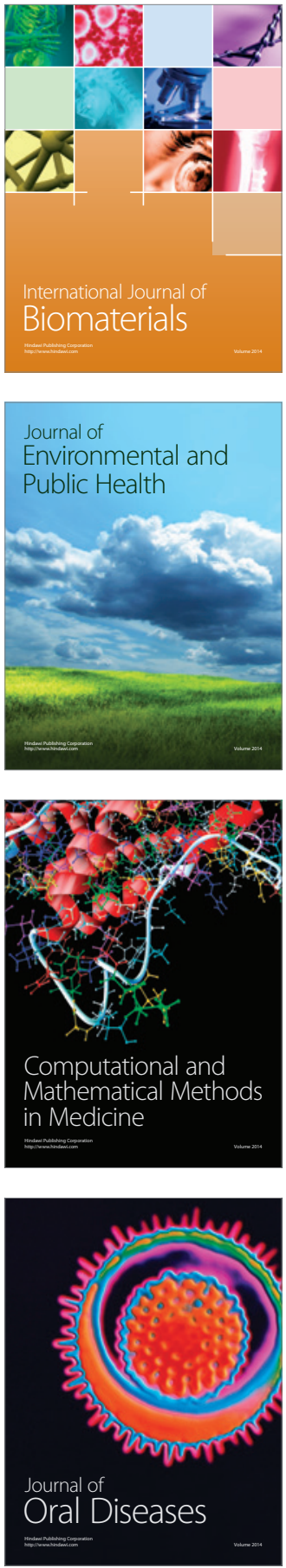
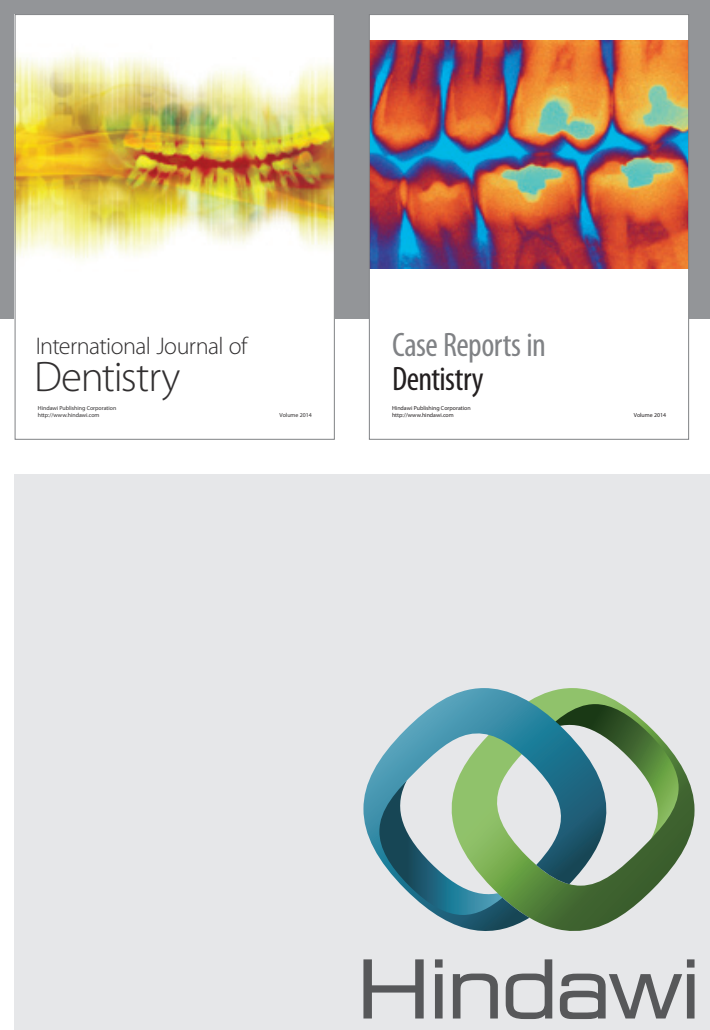

Submit your manuscripts at

http://www.hindawi.com
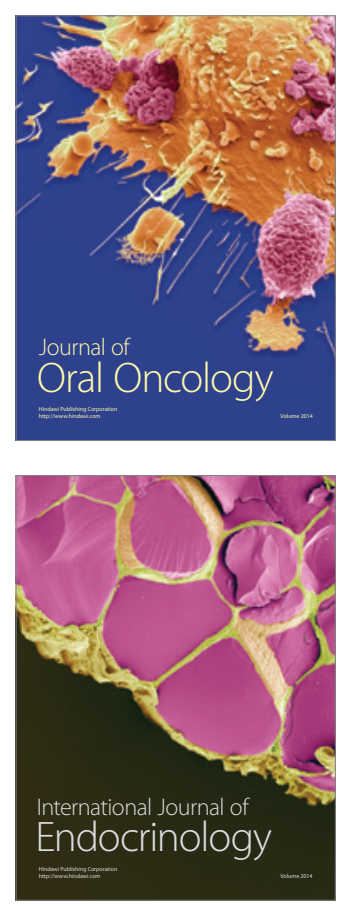
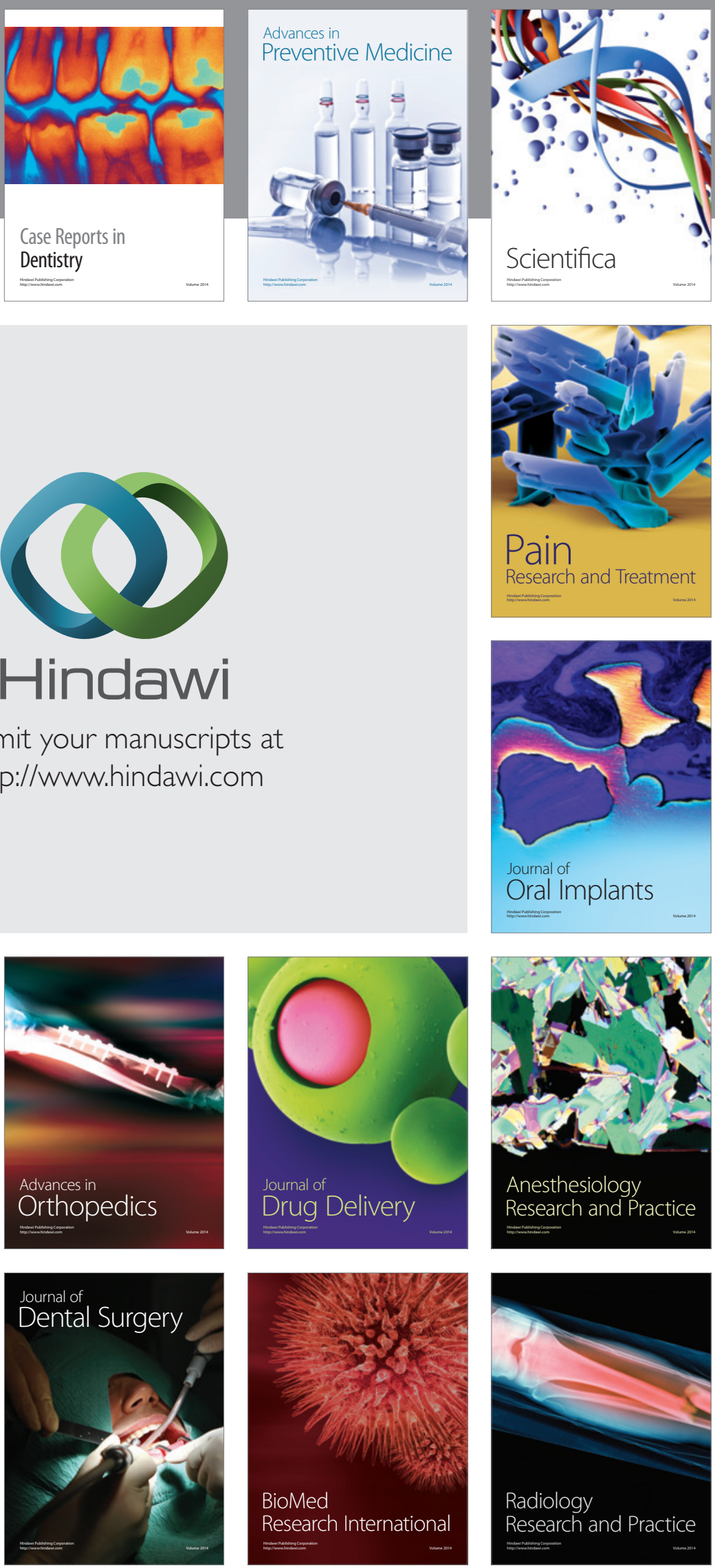